\title{
Responsabilidade Médica
}

$\mathbf{O}$ médico, ao exercer a sua profissão, deve em obediência aos conceitos éticos permeados na sua atividade, zelar e trabalhar pelo perfeito desempenho ético da Medicina e pelo prestígio e bom conceito da profissão.

É o guardião da vida, que é o bem maior que o ser humano possui. O médico deve ter dedicação, correção, respeito pela vida e em razão de sua função agir sempre com diligência, cautela e evitar que seu paciente possa ser conduzido ao sofrimento, a dor, a angústia e as perdas irreparáveis. A responsabilidade do médico e os acontecimentos gerados em decorrência de sua profissão podem gerar efeitos na esfera ética, civil e criminal.

O médico não pode praticar atos profissionais que possam ser danosos ao paciente, e que podem ser caracterizados como imperícia, imprudência e negligência.

A imperícia ocorre quando o médico revela em sua atitude falta ou deficiência de conhecimentos técnicos da profissão. É a falta de observação das normas e despreparo prático necessário para exercer determinada atividade. Devem-se avaliar os progressos científicos que sejam de domínio público, e o profissional deve ter conhecimento para a utilização da técnica indicada para cada tipo de procedimento ou doença. O imperito não sabe, no seu modo de agir, o que um médico deveria saber.

A imprudência é a imprevisão do agente em relação às consequências do seu ato ou ação. O profissional médico tem atitudes, não precipitadas, sem ter cautela, sendo resultado da não racionalização. Neste caso, o médico tem perfeito conhecimento do risco, e ignorando a ciência médica, toma a decisão de agir mesmo assim. O imprudente usa terapêuticas sem necessidade e muitas vezes técnicas terapêuticas que podem ser nocivas para o paciente.

A negligência acontece pela falta de cuidado ou de precaução com que se executam certos atos. É caracterizada pela inércia, indolência, falta de ação e passividade. É um ato omissivo, oposto da diligência que seria agir com cautela, cuidado e atenção, evitando quaisquer distorções e falhas. O negligente não observa a norma técnica que deveria observar, e que todos os outros observam.

O Código de Ética Médica normatiza a responsabilidade ético-disciplinar, zelando pelo cumprimento irrestrito da boa prática médica, e os Conselhos Regionais de Medicina têm a responsabilidade pela fiscalização do exercício da profissão.

O médico deve agir sempre para não produzir ou produzir o menor dano possível ao seu paciente, e tomar as condutas possíveis e notoriamente indicadas que possam minorar o seu sofrimento ou curá-lo.

Na medida em que a Medicina avança e que há a possibilidade de salvar e prolongar a vida, são criados dilemas éticos complexos, que permitem maiores dificuldades para o conceito mais ajustado da existência humana. Acrescente eficácia e a segurança de novas propostas terapêuticas, que não deixam de motivar questionamentos quanto aos aspectos econômicos, éticos e legais, resultantes do emprego desproporcionado das medidas e das possíveis indicações inadequadas de sua aplicação.

O médico deve, a seu paciente, completa lealdade, e empregar ao seu favor todos os recursos da ciência. Na formatura do médico, bem como no recebimento da Carteira Profissional de Médico, o Juramento de Apolo, por ele também jurado, diz que: "Aplicarei os regimes para o bem do doente, segundo o meu poder e entendimento, nunca para causar dano ou mal a alguém. A ninguém darei, por comprazer, nem remédio mortal nem um conselho que o induza a perda".

Ao médico cabe, obrigatoriamente, obedecer ao princípio da não maleficência, ou seja, de não causar mal ou dano ao seu paciente, de não lesar ou danificar as pessoas, podendo-se dizer que "não causar prejuízo ou dano foi a primeira grande norma da conduta eticamente correta para os profissionais da Medicina e do cuidado da saúde".

A Medicina não é uma ciência exata, nem tampouco uma atividade fim, mas sim de meio e, por isso, imprevistos ocorrem e critérios de imprevisibilidade, que cada tratamento ou procedimento tem, deverão 
ser ponderados, objetivando evitar erros inerentes à própria resposta do ser humano.

Como a obrigação do médico é obrigação de meio e não de resultado, o objetivo de um tratamento é o de comportar dentro de uma condição ética, utilizando em sua disponibilidade todos os meios para alcançar a cura do paciente.

Vale lembrar, que o médico é um ser humano que tem a missão de curar e melhorar a qualidade de vida do paciente, e por vezes, quando tal objetivo não é alcançado, ele padece de sofrimento, muitas vezes até mais do que os seus pacientes, que lhes exigem a cura quando esta não pode ser alçada.

Ao médico cabe trabalhar para elevar e dignificar a vida humana, acima de tudo respeitando os valores éticos, morais, religiosos e os costumes e princípios fundamentais da humanidade, bem como o direito indisponível do homem - a vida como um bem maior.

Adamo Lui Netto ${ }^{1}$ Milton Ruiz Alves ${ }^{2}$

1Doutor, Professor Assistente da Faculdade de Ciências Médicas da Santa Casa de São Paulo

${ }^{2}$ Livre-docente, Professor da Faculdade de Medicina da Universidade de São Paulo

\section{Endereço para correspondência}

Av. Indianópolis, 1485; CEP 04063-002 - São Paulo (SP), Brasil

E-mail: adamoluinetto@uol.com.br 